ORIGINAL ARTICLE / ARTIGO ORIGINAL

\title{
All-cause mortality over a three-year period among community-dwelling older adults in Southern Brazil
}

\section{Mortalidade por todas as causas em um período de três anos entre idosos não institucionalizados do Sul do Brasil}

\author{
Ana Clara Ledezma Greiner de Souza' (D), Caroline Cardozo Bortolotto" (D), \\ Andréa Dâmaso Bertoldi" (D), Elaine Tomasi" (D), Flávio Fernando Demarco" (D), \\ Maria Cristina Gonzalez III (D), Renata Moraes Bielemann ${ }^{1, \|, I V}$ (D)
}

\begin{abstract}
Objective: To evaluate all-cause mortality in approximately three years of follow-up and related sociodemographic, behavioral and health factors in community-dwelling older adults in Pelotas, RS. Methods: This was a longitudinal observational study that included 1,451 older adults ( $\geq 60$ years) who were interviewed in 2014. Information on mortality was collected from their households in 2016-2017 and confirmed with the Epidemiological Surveillance department of the city and by documents from family members. Associations between mortality and independent variables were assessed by crude and multiple Cox regression, with hazard ratio with respective $95 \%$ confidence intervals (95\%CI). Results: Almost $10 \%$ $(\mathrm{n}=145)$ of the participants died during an average of 2.5 years of follow-up, with a higher frequency of deaths among males $(12.9 \%)$, $\geq 80$ years $(25.2 \%)$, widowhood $(15.0 \%)$, no education $(13.8 \%)$ and who did not work $(10.5 \%)$. Factors associated with higher mortality were: being a male (HR $=2.8 ; 95 \% \mathrm{CI} 1.9-4.2)$, age $\geq 80$ years $(\mathrm{HR}=3.9 ; 95 \% \mathrm{CI} 2.4-6.2)$, widowhood $(\mathrm{HR}=2.2 ; 95 \% \mathrm{CI} 1.4-3.7)$, physical inactivity $(\mathrm{HR}=2.3$; $95 \% \mathrm{CI} 1.1-4 . .6)$, current smoking $(\mathrm{HR}=2.1 ; 95 \% \mathrm{CI} 1.2-3.6)$, hospitalizations in the previous year $(\mathrm{HR}=2.0$; $95 \% \mathrm{CI} 1.2-3.2$ ), depressive symptoms (HR $=2.0 ; 95 \% \mathrm{CI} 1.2-3,4)$ and dependence for two or more daily life activities $(\mathrm{HR}=3.1 ; 95 \% \mathrm{CI} 1,7-5.7)$. Conclusion: The identification of factors that increased the risk of early death makes it possible to improve public policies aimed at controlling the modifiable risk factors that can lead to aging with a better quality of life.
\end{abstract}

Keywords: Mortality. Risk factors. Health of the elderly. Aging.

'Faculty of Nutrition, Universidade Federal de Pelotas - Pelotas (RS), Brazil.

"Postgraduate Program in Epidemiology, Universidade Federal de Pelotas - Pelotas (RS), Brazil.

I'Postgraduate Program in Health and Behavior, Universidade Católica de Pelotas - Pelotas (RS), Brazil.

"vostgraduate Program in Physical Education, Universidade Federal de Pelotas - Pelotas (RS), Brazil.

Corresponding author: Caroline Cardozo Bortolotto. Programa de Pós-Graduação em Epidemiologia, Universidade Federal de Pelotas. Rua Marechal Deodoro, 1160, Centro, CEP: 96020-220, Pelotas, RS, Brazil. E-mail: kkbortolotto@hotmail.com

Conflict of interests: nothing to declare - Financial support: Postgraduate Program in Epidemiology, Universidade Federal de Pelotas; Coordination for the Improvement of Higher Education Personnel (Capes); master students in the 2013-2014 class; and National Council for Scientific and Technological Development (CNPq). 
RESUMO: Objetivo: Avaliar a mortalidade por todas as causas em aproximadamente três anos de acompanhamento e os fatores sociodemográficos, comportamentais e de saúde em idosos comunitários de Pelotas, Rio Grande do Sul. Métodos: Foi um estudo observacional longitudinal que incluiu 1.451 idosos ( $\geq 60$ anos) entrevistados em 2014. As informações sobre mortalidade foram coletadas nos domicílios em 2016-2017, confirmadas com o setor de Vigilância Epidemiológica do município e por documentos de familiares. As associações entre mortalidade e as variáveis independentes, por regressão de Cox simples e múltipla, foram apresentadas pelos riscos relativos com os respectivos intervalos de confiança (95\%). Resultados: Quase 10\% $(\mathrm{n}=145)$ dos participantes morreram durante uma média de 2,5 anos de acompanhamento, sendo a maior frequência de óbitos em homens (12,9\%), indivíduos com $\geq 80$ anos $(25,2 \%)$ e viúvos $(15,0 \%)$. Estiveram associadas ao maior risco de mortalidade: sexo masculino ( $R R=2,8$; IC95\% 1,9 - 4,2), $\geq 80$ anos (RR = 3,9; IC95\% $2,4-6,2)$, viuvez $(R R=2,2 ;$ IC95\% 1,4 - 3,7), inatividade física $(R R=2,3 ;$ IC95\% 1,1 - 4,6), tabagismo atual $(\mathrm{RR}=2,1$; IC95\% 1,2 - 3,8), hospitalização no último ano (RR = 2,0; IC95\% 1,2 - 3,2), sintomas depressivos $(\mathrm{RR}=2,1$; IC95\% 1,2 - 3,6) e dependência para duas ou mais atividades diárias $(\mathrm{RR}=3,1$; IC95\% $1,7-5,7)$. Conclusão: A identificação dos fatores que aumentaram o risco de óbito precocemente possibilita melhorar políticas públicas que visem controlar os fatores de risco modificáveis para um envelhecimento com melhor qualidade de vida.

Palavras-chave: Mortalidade. Fatores de risco. Saúde do idoso. Envelhecimento.

\section{INTRODUCTION}

Brazil has been showing a new demographic pattern, characterized by a reduction in the population growth rate and by deep changes in the composition of age structure, especially seen by the increase in the representativeness of the elderly population ${ }^{1}$. The percentage of older adults, which in the 1980 s represented $6 \%$ of the Brazilian population, went to $9.8 \%$ in 2005 and $14.3 \%$ in $2015^{2}$, and the estimates point to 33.4 million elderly people by $2025^{3}$, making Brazil rank 5th in the world in absolute numbers of people in this age group 4 .

Changes in the health-disease process are associated with this new demographic profile, which resulted in an increase in life expectancy and a change in the distribution of main death causes among the elderly ${ }^{1}$. On the other hand, the planning of prevention and health promotion policies has not kept pace with the rapid aging of the population and, with regard to the increase in life expectancy of the population, not only the incidence and prevalence of chronic non-communicable diseases (CNCD) has increased, but also the mortality rate from these diseases ${ }^{1}$.

Mortality can be considered an indicator of living conditions and social and economic development ${ }^{5}$, as possible risk factors can be identified in a given population. It is important to evaluate which groups are most vulnerable to mortality in this age group to contribute with the development of public policies aimed at promoting health and preventing death ${ }^{6}$. 
Thus, the present study aimed to verify all-cause mortality in up to three years of follow-up and to identify factors associated in community-dwelling older adults who took part in the cohort study "COMO VAI?" ("HOW ARE YOU?", in free translation), conducted in the city of Pelotas, Rio Grande do Sul.

\section{METHODS}

This longitudinal observational study derives from a larger study entitled "COMO VAI?" ("Consórcio de Mestrado Orientado para a Valorização da Atenção ao Idoso", in English "Master Consortium Oriented to Enhance Elderly Care”). This cross-sectional study took place between January and August 2014, with the objective of evaluating demographic, economic and health characteristics of elderly residents in the urban area of the city of Pelotas, Rio Grande do Sul, Brazil. In 2010, according to data from the Brazilian Institute of Geography and Statistics (IBGE), Pelotas had 330,000 inhabitants (93.3\% in the urban area), where approximately $15 \%$ were considered elderly, mostly women and individuals aged between 60 and 64 years ${ }^{7}$.

Elderly (individuals aged 60 or over), residents of the urban area, non-institutionalized (who were not in long-term care facilities for the elderly, prisons or hospitals) and who had physical and mental conditions to answer the questionnaire in the absence of a caregiver were eligible. The sample size was calculated to meet all the objectives of the study in 2014, considering an increase of $15 \%$ for possible confounding factors and $10 \%$ for losses and refusals. The estimate was at least 1,649 elderly people.

The sampling process had two stages. First, a cluster sampling was used, selecting census sectors using data from the 2010 IBGE Census7. The 488 census sectors in the urban area of Pelotas were listed, ordered according to the average income of each inhabitant. Sectors with 14 or less older adults were grouped to one or more adjacent, with similar average income, totaling 469 eligible sectors. The second phase consisted of selecting the households. The total number of households in the city was 107,152, which was divided by the number of sectors defined by a systematic strategy, with 806 households, implying the inclusion of 133 census sectors out of the 469 eligible. To reach the total estimated sample size, 3,745 households in the urban area should be sampled, systematically selecting 31 households per sector, to find at least 12 elderly people in each of these sectors (estimated 0.4 older adult per household).

The second contact with the sample occurred between November 2016 and April 2017, via telephone and in home interviews. In this second visit, in addition to calls on different days and moments, participants who were not contacted by telephone were contacted in at least four attempts at the addresses provided for the study. As the study was not initially planned to be longitudinal, these search strategies were important to allow the confirmation of basic information such as names and dates of birth, allowing to identify deaths in the Mortality Information System (SIM, acronym in Portuguese). 
Mortality information was assessed in the 2016-2017 data collection and confirmed with the Epidemiological Surveillance sector, based on data from SIM of Pelotas and also on documents from family members certifying the death. In this study, deaths that occurred up to April 30, 2017 were considered. The older adults who refused to participate in the research, as well as those considered losses in the second interview, were considered to be alive due to the lack of information on death from the municipality authorities, as already reported in a previous publication ${ }^{8}$. Losses to follow-up were considered proportional over time. Thus, we assume that they were followed for the average period between the end of the first interview (August 31, 2014) and the beginning of the second interview (November 1, 2016), contributing with person-time at risk for half the period. The second visit or the date of death were used to obtain the follow-up time of the first interview.

The independent variables assessed in 2014 were: sex (male, female), age in complete years (60-69, 70-79, $\geq 80$ years), skin color (white, others), marital status (married or with a partner, single or divorced, widowed), complete years of study (none, $<8, \geq 8$ years), currently working (no or yes), economic status (A/B - wealthier, C, D/E - poorer); from the 2013 Brazil Economic Classification ${ }^{9}$, we had: leisure-time physical activity (individuals who reported at least 150 minutes of weekly physical activity were considered active ${ }^{10}$, smoking (one or more cigarettes per day, in all days, in the last 30 days), categorized as "never smoked", "currently smokes" and "smoked in the past, but stopped", having been hospitalized in the 12 months prior to the interview (yes or no) and depressive symptoms assessed by the presence of five or more symptoms investigated by the Geriatric Depressive Scale $(\text { GDS-10 })^{11}$. The perception of health was measured by the question "How do you define your health?”, with the following response options: very good, good, fair, poor, very bad, later categorized as very good/good, fair, poor/very bad.

The body mass index (BMI) $\left(\mathrm{kg} / \mathrm{m}^{2}\right)$ was obtained from the height estimate by measuring the knee height, using the equation suggested by Chumlea and Guo ${ }^{12}$, and by measuring body weight. The knee height was measured with a children's wooden stadiometer, with a maximum measurement of $100 \mathrm{~cm}$ and accuracy of $0.1 \mathrm{~cm}$ (CMS Weighting Equipment; United Kingdom), while weight was measured using an electronic scale (Tanita brand, model UMB080), with maximum capacity of $150 \mathrm{~kg}$ and accuracy of $100 \mathrm{~g}$. For the assessment of the nutritional status of the elderly, the BMI was categorized according to Lipschitz ${ }^{13}$, with a specific cutoff point for the elderly ${ }^{14}$ : low weight $\left(<22 \mathrm{~kg} / \mathrm{m}^{2}\right)$; eutrophy $\left(\geq 22\right.$ and $\left.\leq 27 \mathrm{~kg} / \mathrm{m}^{2}\right)$; and excess weight $\left(>27 \mathrm{~kg} / \mathrm{m}^{2}\right)$. Functional capacity was analyzed by the Katz et al. ${ }^{15}$ Scale, composed of six items that measure the individual's performance in the following activities of daily living: food, sphincter control, transfer, personal hygiene, ability to dress and bathe. Participants were classified as: independent, dependent for one activity and dependent for two or more activities.

Statistical analyzes were performed on the software Stata 16.0 (Stata Corporation, College Station, USA). Initially, the description of sample characteristics and the outcome 
was obtained in absolute and relative frequencies, with respective $95 \%$ confidence intervals (95\%CI). The speed of death over the study period, according to each factor investigated, was assessed using Cox regression. Crude relative risks (RR) were adjusted for possible confounding factors and respective $95 \% \mathrm{CI}$. The statistical adjustment was made by hierarchical levels, the first level being composed of sociodemographic variables (sex, age, skin color, marital status, complete years of study, current work status and economic situation) and the second level, by behavioral variables (physical activity and smoking). In the third level, the health variables (nutritional status, health perception, having been hospitalized, depressive symptoms, and functional capacity) were inserted. Only variables with $\mathrm{p}<0.20$ (sex, age, marital status, work status and health perception) were maintained in the final analysis model, a process that was performed at each level. The level of statistical significance was set at 5\% for all associations. The "survey" (svy) command was used in all analyses, considering the effect of sampling by clusters.

All stages of the study were approved by the Research Ethics Committee of the Medical School of Universidade Federal de Pelotas - CAAE: 54141716.0.0000.5317. The individuals who participated in the research, or their caregivers, signed the free and informed consent form, assuring data confidentiality. In 2016-2017, the informed consent form was signed by family members or informers of the occurrence of deaths. For the elderly people interviewed by phone, consent was given verbally by their acceptance to answer the questionnaire.

\section{RESULTS}

In $2014,1,844$ elderly people were allocated in the baseline study, $78.7 \%$ of whom were interviewed $(\mathrm{n}=1,451)$. Losses and refusals totaled 393 individuals $(21.3 \%)$, being higher among women $(59.3 \%)$ and the aged between 60 and 69 years $(59.5 \%)$. In the second follow-up, 1,298 elderly people were found (including 145 deaths identified), with a follow-up rate of $89.5 \%$ of 1,451 respondents in 2014 .

The total refusals and losses in 2016-2017 were 61 and 92 (10.5\%), respectively. Between 2014 and 2016-2017, men and women were followed up equally ( $p=0.319)$. The same occurred according to the age of the elderly $(\mathrm{p}=0.305)$. Widow(er)s were less likely to be followed up ( $\mathrm{p}=0.001)$. No statistical difference was found in follow-up rates as to skin color, education, economic level and health perception. Overweight $(\mathrm{p}=0.019)$, physically active elderly $(\mathrm{p}<0.001)$ and individuals who never smoked $(\mathrm{p}=0.015)$ were more likely to be followed up (data not shown in table).

The sociodemographic characteristics of the interviewees in 2014 are shown in Table 1. Most of the 1,451 individuals interviewed were women (63.0\%), aged between 60 and 69 years $(52.3 \%)$, white skin color $(83.7 \%)$, married or with a partner $(52.7 \%)$, with $<8$ years of schooling $(54.4 \%)$, not economically active $(80.4 \%)$ and belonging to socioeconomic level C (52.5\%). 
Table 1. Description of the sample of elderly people living in Pelotas according to socioeconomic and demographic characteristics, Rio Grande do Sul, 2014.

\begin{tabular}{|c|c|c|}
\hline Characteristics & $\mathrm{n}(\%)$ & $95 \% \mathrm{Cl}$ \\
\hline Sex (male) $(n=1,451)$ & $537(37.0)$ & $34.6-40.0$ \\
\hline \multicolumn{3}{|l|}{ Age $(n=1,446)$} \\
\hline $60-69$ & $756(52.3)$ & $49.7-54.9$ \\
\hline $70-79$ & $460(31.8)$ & $29.5-34.3$ \\
\hline$\geq 80$ & $230(15.9)$ & $14.1-18.0$ \\
\hline Skin color (others) $(n=1,447)$ & $236(16.3)$ & $14.5-18.3$ \\
\hline \multicolumn{3}{|l|}{ Marital status $(n=1,447)$} \\
\hline married & $763(52.7)$ & $50.2-55$ \\
\hline single & $225(15.6)$ & $13.8-17.5$ \\
\hline widow(er) & $459(31.7)$ & $29.3-34.2$ \\
\hline \multicolumn{3}{|l|}{ Schooling $(n=1,437)$} \\
\hline None & $196(13.6)$ & $12.0-15.5$ \\
\hline $1-7$ years & $782(54.4)$ & $51.8-57.0$ \\
\hline 8 years or more & $459(31.9)$ & $29.6-34.4$ \\
\hline Currently works (no) $(\mathrm{n}=1,348)$ & $1.084(80.4)$ & $17.6-21.8$ \\
\hline \multicolumn{3}{|l|}{ Socioeconomic status $(n=1,372)$} \\
\hline A/B (richer) & $483(35.2)$ & $32.7-37.8$ \\
\hline C & $720(52.5)$ & $50.0-55.1$ \\
\hline D/E (poorer) & $169(12.3)$ & $10.7-14.2$ \\
\hline
\end{tabular}

95\% Cl: 95\% confidence interval.

As for behavior and health features (Table 2), most participants were classified as inactive for leisure-time physical activity (81.4\%) and never smoked (54\%). In addition, $56.2 \%$ of the sample was overweight and $53.1 \%$ rated their own health as good or very good. Around $12 \%$ had been hospitalized in the 12 months prior to the interview, $15.2 \%$ had depressive symptoms, and $63.9 \%$ were functionally independent.

In up to three years of follow-up (mean follow-up time $=2.5$ years and $\mathrm{SD}=0.6$ years), almost $10 \%$ of the participants died $(n=145)$. The percentage of deaths was higher among males $(\mathrm{p}=0.006)$, the aged 80 or over $(\mathrm{p}<0.001)$, widow $(\mathrm{er}) \mathrm{s}(\mathrm{p}<0.001)$, 
Table 2. Description of the sample of elderly residents in Pelotas, according to behavioral and health characteristics, Rio Grande do Sul, 2014.

\begin{tabular}{|c|c|c|}
\hline Characteristics & $\mathrm{n}(\%)$ & $95 \% \mathrm{Cl}$ \\
\hline Physical inactivity ${ }^{\text {(yes) }}(\mathrm{n}=1,391)$ & $1,133(81.4)$ & $19.3-20.7$ \\
\hline \multicolumn{3}{|l|}{ Smoking $(n=1,446)$} \\
\hline Never smoked & $781(54.0)$ & $51.4-56.6$ \\
\hline Former smoker & $483(33.4)$ & $31.0-35.9$ \\
\hline Current smoker & $182(12.6)$ & $11.0-14.4$ \\
\hline \multicolumn{3}{|l|}{ Nutritional status $(n=1,364)$} \\
\hline Low weight & $126(9.3)$ & $7.8-10.9$ \\
\hline Eutrophy & $471(34.5)$ & $32.1-37.1$ \\
\hline Overweight & $767(56.2)$ & $53.6-58.8$ \\
\hline \multicolumn{3}{|l|}{ Health perception $(n=1,442)$} \\
\hline Good/very good & $765(53.1)$ & $50.5-55.6$ \\
\hline Regular & $545(37.8)$ & $35.3-40.3$ \\
\hline Bad/very bad & $132(9.2)$ & $7.8-10.8$ \\
\hline Hospitalization $^{b}$ (yes) $(n=1,447)$ & $176(12.2)$ & $10.6-14.0$ \\
\hline Depressive symptoms (yes) $(n=1,394)$ & $212(15.2)$ & $13.4-17.2$ \\
\hline \multicolumn{3}{|l|}{ Functional capacity $(n=1,440)$} \\
\hline Not dependent & $920(63.9)$ & $61.4-66.3$ \\
\hline Dependent (1 task) & $395(27.4)$ & $25.2-29.8$ \\
\hline Dependent ( $\geq 2$ tasks) & $125(8.7)$ & $7.3-10.3$ \\
\hline
\end{tabular}

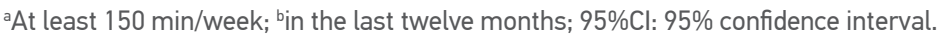

individuals with lower education $(\mathrm{p}=0.033)$ and who did not work in $2014(\mathrm{p}=0.003)$ (Table 3). The highest proportion of deaths also included those who were physically inactive during leisure time $(\mathrm{p}=0.002)$, individuals with low weight $(\mathrm{p}=0.003)$ and participants who had been hospitalized in the year prior to the interview $(\mathrm{p}<0.001)$. Among the elderly who had depressive symptoms, mortality was also higher compared to others without any symptoms $(\mathrm{p}=0.001)$; those considered dependent for two or more functional activities of daily living $(\mathrm{p}<0.001)$ also accounted for more deaths than those functionally independent (Table 4). 
Table 3. Description and association of all-cause mortality of elderly people living in Pelotas, according to socioeconomic and demographic characteristics, Rio Grande do Sul, 2017 ( $n=145)$.

\begin{tabular}{|c|c|c|c|c|c|c|}
\hline Characteristics & n (\%) & $95 \% \mathrm{Cl}$ & Crude RR & $\mathrm{p}$ value & Adjusted RR & $p$ value \\
\hline Sex (male) & $\begin{array}{c}69 \\
(12.9)\end{array}$ & $10.0-16.4$ & $\begin{array}{c}1.6 \\
(1.1-2.2)\end{array}$ & 0.006 & $\begin{array}{c}2.8 \\
(1.9-4.2)\end{array}$ & $<0.001$ \\
\hline Age & & & & $<0.001$ & & $<0.001$ \\
\hline $60-69$ & $\begin{array}{c}41 \\
(5.4)\end{array}$ & $4.1-7.2$ & Ref. & & Ref. & \\
\hline $70-79$ & $\begin{array}{c}46 \\
(10.0)\end{array}$ & $7.4-13.3$ & $\begin{array}{c}1.9 \\
(1.2-2.9)\end{array}$ & & $\begin{array}{c}1.7 \\
(1.0-2.7)\end{array}$ & \\
\hline$\geq 80$ & $\begin{array}{c}57 \\
(25.2)\end{array}$ & $19.6-31.8$ & $\begin{array}{c}5.2 \\
(3.5-7.8)\end{array}$ & & $\begin{array}{c}3.9 \\
(2.4-6.2)\end{array}$ & \\
\hline Skin color (others) & $\begin{array}{c}27 \\
(11.4)\end{array}$ & $7.3-17.4$ & $\begin{array}{c}1.1 \\
(0.7-1.7)\end{array}$ & 0.572 & $\begin{array}{c}1.1 \\
(0.7-1.7)\end{array}$ & 0.748 \\
\hline Marital status $^{a}$ & $\begin{array}{c}69 \\
(15.0)\end{array}$ & $11.9-18.8$ & $\begin{array}{c}2.0 \\
(1.5-3.0)\end{array}$ & $<0.001$ & $\begin{array}{c}2.2 \\
(1.4-3.7)\end{array}$ & 0.002 \\
\hline Schooling ${ }^{b}$ & $\begin{array}{c}27 \\
(13.8)\end{array}$ & $9.8-19.0$ & $\begin{array}{c}1.9 \\
(1.0-3.2)\end{array}$ & 0.033 & $\begin{array}{c}1.2 \\
(0.6-2.1)\end{array}$ & 0.746 \\
\hline Currently works (no) & $\begin{array}{c}114 \\
(10.5)\end{array}$ & $8.8-12.6$ & $\begin{array}{c}2.5 \\
(1.4-4.4)\end{array}$ & 0.003 & $\begin{array}{c}1.8 \\
(1.0-3.4)\end{array}$ & 0.053 \\
\hline Socioeconomic status ${ }^{c}$ & $\begin{array}{c}20 \\
(11.8)\end{array}$ & $7.9-17.4$ & $\begin{array}{c}1.3 \\
(0.8-2.3)\end{array}$ & 0.573 & $\begin{array}{c}1.1 \\
(0.6-1.9)\end{array}$ & 0.763 \\
\hline
\end{tabular}

aWidow(er)s as opposed to married people; ${ }^{\mathrm{b}}$ no schooling as opposed to 8 years or more of study; 'class D/E (poorest) as opposed to $\mathrm{A} / \mathrm{B}$ (richest); $95 \% \mathrm{Cl}$ : $95 \%$ confidence interval; RR: relative risk.

In the adjusted analysis, there was a higher risk of death among men $(\mathrm{RR}=2.8 ; 95 \% \mathrm{CI}$ 1.9 - 4.2), individuals aged 80 years or older $(\mathrm{RR}=3.9 ; 95 \% \mathrm{CI} 2.4-6.2)$ and those who were widowed at the time of the interview ( $\mathrm{RR}=2.2 ; 95 \% \mathrm{CI} 1.4-3.7)$ (Table 3 ).

After adjusting for possible confounding factors, there was a higher risk of death among inactive participants $(\mathrm{RR}=2.3 ; 95 \% \mathrm{CI} 1.1$ - 4.6), smokers $(\mathrm{RR}=2.1 ; 95 \% \mathrm{CI} 1.2-3.6)$ and individuals showing depressive symptoms $(\mathrm{RR}=2.0 ; 95 \% \mathrm{CI} 1.2-3.4)$. In addition, those who had been hospitalized in the year prior to the 2014 interviews ( $R R=2.0 ; 95 \%$ CI 1.2 $3.2)$ and dependents for two or more functional activities (RR $=3.1 ; 95 \% \mathrm{CI} 1,7-5,7)$ were also classified as the group with the highest risk of death. There was no statistically significant association with nutritional status and health perception (Table 4). 
Table 4. Description and association of mortality of elderly people living in Pelotas, according to behavioral and health characteristics, Rio Grande do Sul, 2017 ( $n=145)$.

\begin{tabular}{|c|c|c|c|c|c|c|}
\hline Characteristics & $\mathrm{n}(\%)$ & $95 \% \mathrm{Cl}$ & Crude RR & $p$ value & Adjusted RR & $\mathrm{p}$ value \\
\hline Physical inactivitya (yes) & $\begin{array}{l}110 \\
(9.7)\end{array}$ & $8.1-11.7$ & $\begin{array}{c}2.9 \\
(1.5-5.70)\end{array}$ & 0.002 & $\begin{array}{c}2.3 \\
(1.1-4.6)\end{array}$ & 0.019 \\
\hline Smoking (current) ${ }^{b}$ & $\begin{array}{c}23 \\
(12.6)\end{array}$ & $8.3-18.8$ & $\begin{array}{c}1.1 \\
(0.9-1.3)\end{array}$ & 0.292 & $\begin{array}{c}2.1 \\
(1.2-3.6)\end{array}$ & 0.023 \\
\hline Nutritional status ${ }^{c}$ & $\begin{array}{l}49 \\
(6.4)\end{array}$ & $4.8-8.4$ & $\begin{array}{c}0.7 \\
(0.5-1.1)\end{array}$ & 0.003 & $\begin{array}{c}1.0 \\
(0.6-1.6)\end{array}$ & 0.476 \\
\hline Health perception ${ }^{d}$ & $\begin{array}{c}26 \\
(19.7)\end{array}$ & $13.4-28.1$ & $\begin{array}{c}4.1 \\
(2.5-7.6)\end{array}$ & $<0.001$ & $\begin{array}{c}1.9 \\
(0.9-3.8)\end{array}$ & 0.067 \\
\hline Hospitalizatione (yes) & $\begin{array}{c}43 \\
(24.4)\end{array}$ & $18.9-30.9$ & $\begin{array}{c}3.5 \\
(2.4-4.9)\end{array}$ & $<0.001$ & $\begin{array}{c}2.0 \\
(1.2-3.2)\end{array}$ & 0.009 \\
\hline $\begin{array}{l}\text { Depressive symptoms } \\
\text { (yes) }\end{array}$ & $\begin{array}{c}31 \\
(14.6)\end{array}$ & $10.6-19.9$ & $\begin{array}{c}2.0 \\
(1.3-3.0)\end{array}$ & 0.001 & $\begin{array}{c}2.0 \\
(1.2-3.4)\end{array}$ & 0.005 \\
\hline Functional capacity & & & & $<0.001$ & & $<0.001$ \\
\hline Not dependent & $\begin{array}{c}58 \\
(6.3)\end{array}$ & $4.9-8.1$ & Ref. & & Ref. & \\
\hline Dependent (1 task) & $\begin{array}{c}31 \\
(7.9)\end{array}$ & $5.6-10.9$ & $\begin{array}{c}1.2 \\
(0.8-1.9)\end{array}$ & & $\begin{array}{c}1.0 \\
(0.6-1.6)\end{array}$ & \\
\hline Dependent ( $\geq 2$ tasks) & $\begin{array}{c}54 \\
(43.2)\end{array}$ & $35.0-51.8$ & $\begin{array}{c}8.9 \\
(6.1-12.9)\end{array}$ & & $\begin{array}{c}3.1 \\
(1.7-5.7)\end{array}$ & \\
\hline
\end{tabular}

a Less than $150 \mathrm{~min} /$ week; ${ }^{b}$ current smoking compared to non-smoker; 'overweight in relation to eutrophy; ${ }^{\mathrm{d}}$ perception of poor/very poor health in relation to perception of good/very good health; ein the last twelve months; $95 \% \mathrm{Cl}: 95 \%$ confidence interval; RR: relative risk.

\section{DISCUSSION}

This study aimed to identify the mortality rate in up to three years of follow-up and the factors associated with a higher risk of death. One in ten elderly people died during the follow-up period and the risk of dying was higher among men, older individuals and widow(er)s. The same relationship was observed for physical inactivity, being a smoker, having depressive symptoms, having been hospitalized, and presenting worse functional capacity.

Several studies show a higher risk of death among men ${ }^{16-18}$. The search for healthier lifestyles and the greater demand for and use of health services among the female population, 
whether for promotion or prevention/assistance, are a possible explanation for this finding $^{19}$. In addition, men tend to seek medical care at later stages or even ignore the symptoms of some diseases ${ }^{20}$.

Mortality rates among elderly Brazilians increase with age for both sexes. Maia et al., when evaluating elderly people from the city of São Paulo in the multicenter study "Health, well-being and aging" (SABE), reported that being 75 years old or older was related to a higher risk of death ${ }^{17}$. The same risk was observed in a longitudinal study in developed countries, but the age group with the highest risk was 70-75 years ${ }^{21}$.

Regarding marital status, a meta-analysis showed that, in general, widow(er)s are related to a higher mortality rate, in addition to low satisfaction with life, poor economic situation and greater risk of serious and minor psychiatric conditions ${ }^{22}$. A cohort study carried out by Gomes et al., in the city of São Paulo, found that, among both male and female elderly, the mortality rate of individuals without a partner or in a situation of separation/divorce and widowhood was higher than the observed for married individuals, or those who lived with a partner ${ }^{23}$. The feeling of loneliness is quite common among widow(er) $\mathrm{s}^{24}$. In addition, increased loneliness and reduced social support are common consequences of later widowhood and are linked to a higher risk of mortality, especially among males ${ }^{25}$.

Additionally, an exploratory analysis in our study showed that, among married individuals, $92.6 \%$ were part of the economic classes A/B and C; in this sense, a better economic situation, social support and control in better health behaviors are possible explanations for the protective effect of marriage for death causes that could be preventable in this population.

In view of the lower proportion of deaths among employed individuals, it is known that some countries have sought alternatives to "keep their elderly citizens socially and economically integrated and independent”, by, for example, encouraging private systems to offer opportunities for the continuity of working life and employment in old age ${ }^{26}$. In addition to the economic scope, work in the elderly positively influences their social participation, thus keeping them active, encouraging relationships with friends, cooperation and interactivity $^{26}$. The relationship between work and lower risk of death may be due to the younger age of the elderly who are still economically active, in addition to a lower occurrence of disability among them.

With regard to behavioral factors, it is known that physical inactivity, excessive alcohol consumption and smoking tend to occur concurrently ${ }^{27}$. These behaviors are the main predictors of morbidity and mortality in the elderly ${ }^{28}$. It is also known that the greater the longevity, the less likely the practice of physical activity in the elderly ${ }^{28}$. Recently, a cohort study showed that elderly people with cardiovascular diseases and cancer can get substantial benefits in longevity by becoming more physically active, regardless of past levels of physical activity and established risk factors ${ }^{29}$.

Regarding smoking, an association between mortality and smoking was found, as previously observed in other studies ${ }^{20,30,31}$. Tobacco use is associated with worse health status 
and quality of life, in addition to being a risk factor for premature mortality and disabilities due to cardiovascular diseases, chronic obstructive pulmonary disease (COPD), cancer, among others ${ }^{31}$.

Health perception has been used as a marker capable of pointing, among others, mortality rates, but this association was not found in the present study. Elderly people who report their health negatively have a higher risk of all-cause mortality when compared to elderly people who perceive their health positively ${ }^{17-20}$. With regard to the number of hospitalizations, in the same direction observed in this study, Schonberg et al. found that elderly people who had been hospitalized were 1.8 times more likely to die; for those who had been hospitalized twice or more, mortality was 3 times higher $^{32}$.

Regarding depressive symptoms, a study carried out with elderly people in Brazil found that $14.2 \%$ had depressive symptoms (GDS-15), a value close to ours $(15.2 \%)^{33}$. A recent meta-analysis that evaluated depression and mortality in the elderly in low- and middle-income countries, including Brazil, reported a positive association between depression and mortality in the elderly ${ }^{34}$. Untreated depression, associated with existing pathologies, can aggravate illnesses, worsen the quality of life of the elderly and increase mortality rates ${ }^{35-37}$. In Greece, moderate to severe depression (GDS-15) was significantly associated with a 51\% increase in all-cause mortality ${ }^{35}$.

The presence of morbidities associated with aging and the natural losses that occur in this age group also corroborate an early functional decline and, consequently, a worse quality of life and high mortality rates ${ }^{33,35}$. A cohort study conducted in the city of Florianópolis, Santa Catarina, indicated a prevalence of $31.5 \%$ of functional disability and highlighted the difficulty/inability to walk and bathe, which increased the risk of mortality by almost three times ${ }^{36}$. In the United States, $18 \%$ of the elderly were reported to be dependent for at least one daily activity and had a greater chance of early mortality $^{34}$. These results support the hypothesis that most mortality predictors in old age do not vary between populations.

The growing presence of elderly people in society imposes the challenge of inserting the theme of population aging in the formulation of public policies and of implementing prevention and care actions directed to their needs. Thus, it is essential to orientate the planning of public policies and services to the strengthening of autonomy and the promotion of a healthy life for the elderly by physical activity, control of overweight and identification and treatment of depression, in order to ensure adequate care to their needs ${ }^{37}$.

This study has different positive and negative characteristics. Positive points are: the research is population-based, with a representative sample of the elderly. It is also worth mentioning the double checking of deaths (registration in SIM and households) and the information about different social, demographic, behavioral and health characteristics. Some of the negative aspects are: the time of the study may have been insufficient to check some associations, but it made it possible to identify associations with more proximate determinants of mortality, such as physical inactivity, smoking, depressive symptoms, hospitalizations, and functional capacity. The fact that less than 
$10 \%$ of the sample perceived their health as very poor/poor health may have reduced the statistical power to find an association between worse health perception and mortality. Survival bias should also be considered. The sample consisted of people who have reached old age, that is, they have survived at least six decades, and individuals more exposed to risk factors are more likely to die prematurely, reducing the magnitude of the associations found.

Sociodemographic, behavioral and health characteristics associated with a higher risk of mortality in the elderly were identified. The use of mortality as an indicator of living conditions and social/economic development ${ }^{5}$ allows to understand which factors influence the mortality of the elderly, helping to improve public policies for this population, aiming to fight preventable or modifiable health factors and allowing them to enjoy longevity with a better quality of life.

\section{REFERENCES}

1. GBD 2016 Brazil Collaborators. Burden of disease in Brazil, 1990-2016: a systematic subnational analysis for the Global Burden of Disease Study 2016. Lancet 2018; 392(10149): 760-75. https:// doi. org/10.1016/s0140-6736(18)31221-2

2. Instituto Brasileiro de Geografia e Estatística. Censo Demográfico. Síntese de indicadores sociais uma análise das condições de vida. Brasil: Instituto Brasileiro de Geografia e Estatística; 2016.

3. Carvalho MF, Romano-Lieber NS, Bergsten-Mendes G, Secoli SR, Ribeiro E, Lebrão ML, et al. Polypharmacy among the elderly in the city of São Paulo, BrazilSABE Study. Rev Bras Epidemiol 2012; 15(4): 817-27. https: / / doi.org/10.1590/s1415-790x2012000400013

4. Organização Mundial da Saúde. Envelhecimento ativo: uma política de saúde. Brasília: OPAS; 2005.

5. Borges GM. Health transition in Brazil: regional variations and divergence/convergence in mortality. Cad Saúde Pública 2017; 33(8): e00080316. https:// doi.org/10.1590/0102-311x00080316

6. Lima-Costa MF, Matos DL, Camarano AA. Evolução das desigualdades sociais em saúde entre idosos e adultos brasileiros: um estudo baseado na Pesquisa Nacional por Amostra de Domicílios (PNAD 1998, 2003). Ciênc Saude Coletiva 2006; 11(4): 941-50. https:// doi.org/10.1590/S1413-81232006000400016

. Instituto Brasileiro de Geografia e Estatística (IBGE). Censo Demográfico 2010: Características da População e dos Domicílios. Resultados do Universo [Internet]. Rio de Janeiro: IBGE; 2011 [accessed on Feb. 12,
2020]. Available at: https://biblioteca.ibge.gov.br/ visualizacao/periodicos/93/cd_2010_caracteristicas_ populacao_domicilios.pdf

8. Bielemann RM, LaCroix AZ, Bertoldi AD, Tomasi E, Demarco FF, Gonzalez MC, et al. Objectively Measured Physical Activity Reduces the Risk of Mortality among Brazilian Older Adults. J Am Geriatr Soc 2020; 68(1): 137-46. https: / / doi.org/10.1111/jgs.16180

8. Associação Brasileira de Empresas de Pesquisa (ABEP). Alterações na aplicação do Critério Brasil, válidas a partir de 2013 [Internet]. Brasil: ABEP; 2013 [accessed on Nov. 23, 2019]. Available at: http: / /www.abep.org/ criterio-brasil

10. World Health Organization. Global Physical Activity Questionnaire (GPAQ): Analysis Guide. Genebra: World Health Organization; 2010.

11. Sheikh JI, Yesavage JA. Geriatric Depression Scale (GDS): recent evidence and development of a shorter version. Clin Gerontol 1986; 5(1-2): 165-73. https:// doi.org/10.1300/J018v05n01_09

12. Chumlea WC, Guo S. Equations for predicting stature in white and black elderly individuals. J Gerontol 1992; 47(6): M197-203. https:/ / doi.org/10.1093/geronj/47.6.m197

13. Lipschitz DA. Screening for nutritional status in the elderly. Prim Care 1994; 21(1): 55-67.

14. American Academy of Family Physicians. American Dietetic Association. National Council on the Aging Inc. Incorporating Nutrition Screening and Interventions into Medical Practice. The Nutrition Screening Initiative; 1994. 
15. Katz S, Ford AB, Moskowitz RW, Jackson BA, Jaffe MW. Studies of illness in the aged: the index of ADL: a standardized measure of biological and psychosocial function. JAMA 1963; 185: 914-9. https: / doi.org/10.1001/jama.1963.03060120024016

16. Gontijo CF, Firmo JO, Lima-Costa MF, Loyola Filho AI. Um estudo longitudinal da associação do capital social e mortalidade entre idosos brasileiros residentes em comunidade. Cad Saúde Pública 2019; 35(2): e00056418. https:// doi. org/10.1590/0102-311x00056418

17. Maia FOM, Duarte YAO, Lebrão ML, Santos JLF. Risk factors for mortality among elderly people. Rev Saúde Pública 2003; 40(6): 1054-56. https: / / doi.org/10.1590/ S0034-89102006005000009

18. Lima-Costa MF, Peixoto SV, Matos DL, Firmo JOA, Uchôa E. Determinantes da mortalidade em 10 anos de idosos brasileiros residentes na comunidade: Estudo de Coorte de Idosos de Bambuí. Cad Saúde Pública 2011; 27(Supl. 3): s360-s369. https: / / doi.org/10.1590/ S0102-311X2011001500006

19. Organização Mundial da Saúde (OMS). Mortalidade. Genebra: Organização Mundial da Saúde; 2020 [accessed on Dec 19, 2020]. Available at: http:// www.who.int/topics/mortality/en/

20. Oliveira MM, Daher DV, Silva JL, Andrade SSCA. A saúde do homem em questão: busca por atendimento na atenção básica de saúde. Ciênc Saúde Coletiva 2015; 20(1): 273-8. https://doi. org/10.1590/1413-81232014201.21732013

21. Haveman-Nies A, Groot LPMG, Burema J, Cruz JAA, Osler M, Staveren WA. Dietary quality and lifestyle factors in relation to 10 -year mortality in older Europeans: the SENECA study. Am L Epidemiol 2002; 156(10): 962-8. https:/ / doi.org/10.1093/aje/ kwf144

22. Roelfs DJ, Shor E, Curreli M, Clemow L, Burg MM, Schwartz JE. Widowhood and mortality: a meta-analysis and meta-regression. Demography 2012; 49(2): 575-606. https:// doi.org/10.1007/ s13524-012-0096-x

23. Gomes MMF, Turra CM, Fígoli MGB, Duarte YA, Lebrão ML. Associação entre mortalidade e estado marital: uma análise para idosos residentes no Município de São Paulo, Brasil, Estudo SABE, 2000 e 2006. Cad Saúde Pública 2013; 29(3): 566-78. https: / / doi.org/10.1590/S0102-311X2013000300014

24. Rico-Uribe LA, Caballero FF, Martín-María N, Cabello M, Ayuso-Mateos JL, Miret M. Association of loneliness with all-cause mortality: A meta-analysis. PloS One 2018; 13(1): e0190033. https://doi.org/10.1371/journal. pone. 0190033
25. King BM, Carr DC, Taylor MG. Loneliness following widowhood: the role of the military and social support. J Gerontol B Psychol Sci Soc Sci 2021; 76(2): 403-14. https: / / doi.org/10.1093/geronb/gbz164

26. Kalache A. O mundo envelhece: é imperativo criar um pacto de solidariedade social. Ciênc Saúde Coletiva 2008; 13(4): 1107-11. https:// doi.org/10.1590/ S1413-81232008000400002

27. Lee IM, Shiroma EJ, Lobelo F, Puska P, Blair SN, Katzmarzyk PT. Effect of physical inactivity on major non-communicable diseases worldwide: an analysis of burden of disease and life expectancy. Lancet 2012; 380(9838): 219-29. https://doi.org/10.1016/ s0140-6736(12)61031-9

28. Feldman DI, Al-Mallah MH, Keteyian SJ, Brawner CA, Feldman T, Blumenthal RS, et al. No evidence of an upper threshold for mortality benefit at high levels of cardiorespiratory fitness. J Am Col Cardiol 2015; 65(6): 629-30. https:// doi.org/10.1016/j.jacc.2014.11.030

29. Mok A, Khaw KT, Luben R, Wareham N, Brage S. Physical activity trajectories and mortality: population based cohort study. BMJ 2016; 365: 12323. https:/ / doi. org / 10.1136/bmj.12323

30. Ferreira TC, Coimbra AM, Falsarella GR, Costallat LT, Coimbra IB. Mortality in Brazilian communitydwelling older adults: 7 years of follow up in primary care. Geriatr Gerontol Int 2016; 16(7): 804-9. https: / / doi.org/10.1111/ggi.12561

31. José BPS, Corrêa RA, Malta DC, Passos VMA, França EB, Teixeira RA, et al. Mortalidade e incapacidade por doenças relacionadas à exposição ao tabaco no Brasil, 1990 a 2015. Rev Bras Epidemiol 2017; 20(Supl. 1): 75-89. https:// doi. org/10.1590/1980-5497201700050007

32. Schonberg MA, Davis RB, McCarthy EP, Marcantonio ER. Index to predict 5-year mortality of communitydwelling adults aged 65 and older using data from the National Health Interview Survey. J Gen Intern Med 2009; 24(10): 1115-22. https: / / doi.org/10.1007/ s11606-009-1073-y

33. Mendes-Chiloff CL, Lima MCP, Torres AR, Santos JLF, Duarte YO, Lebrão ML, et al. Sintomas depressivos em idosos do município de São Paulo, Brasil: prevalência e fatores associados (Estudo SABE). Rev Bras Epidemiol 2018; 21(Supl. 2): e180014. https:// doi.org/10.1590/1980-549720180014.supl.2

34. Brandão DJ, Fontenelle LF, Silva SA, Menezes PR, Pastor-Valero M. Depression and excess mortality in the elderly living in low-and middle-income countries: systematic review and meta-analysis. Int J Geriatr Psychiatr 2019; 34(1): 22-30. https: / / doi.org/10.1002/ gps.5008 
35. Georgakis MK, Papadopoulos FC, Protogerou AD, Pagonari I, Sarigianni F, Biniaris-Georgallis SI, et al. Comorbidity of cognitive impairment and late-life depression increase mortality: results from a cohort of community-dwelling elderly individuals in rural Greece. J Geriatr Psychiatr Neurol 2016; 29(4): 195 204. https: / / doi.org/10.1177/0891988716632913

36 Ono LM. Capacidade funcional como preditor de mortalidade em idosos de Florianópolis: Estudo Epi Floripa Idoso [dissertação]. Florianópolis: Centro de Ciências da Saúde, Universidade Federal de Santa Catarina; 2015.

37. Miranda GMD, Mendes ACG, Silva ALA. O envelhecimento populacional brasileiro: desafios e consequências sociais atuais e futuras. Rev Bras
Geriatr Gerontol 2016; 19(3): 507-19. https:// doi. org/10.1590/1809-98232016019.150140

Received on: 06/27/2020

Revised on: 10/16/2020

Accepted on: 10/20/2020

Authors' contribution: RMB, ADB, ET, FFD and MCG participated in the conception and design of the study. ACLGS, CCB and RMB contributed with data analysis and interpretation, and by critically reviewing and approving the final version. $\mathrm{ADB}$, ET, FFD and MCG collaborated with the revision of the final version of the manuscript. 